\title{
Financial Management Education: Is there a Gap between Academics and Practitioners?
}

\section{H P Wolmarans}

\section{Graduate School of Management, University of Pretoria}

\section{ABSTRACT}

From previous studies it seems that Financial Management may be regarded an important managerial skill. This study investigates the importance of different topics in Finance. The ranking of these topics according to their importance, as perceived by academics versus practitioners, is compared here. It was found that some topics are indeed regarded as more important than others. There were significant differences in the rankings of topics by the two groups of respondents. Areas which practitioners believe need more research to enhance the value of Finance for South African managers are indicated. Finally, conclusions are drawn about the implications of this study for the volatile management environment in South Africa, and possible areas for further research are indicated.

JEL G30

\section{INTRODUCTION}

Most experts would agree that Financial Management as a discipline can be regarded as one of the most valuable skills in the proverbial kitbag of a typical business manager. In a follow-up study of the career experiences of MBA graduates at least 5 years after graduation, a number of MBA alumni of a wellknown South African business school were requested to rank management disciplines in the order of importance perceived by them, in the light of the present as well as expected future business situation in South Africa (Jonker, 1997:125). In both rankings the discipline of Financial Management was placed first. Seeing that respondents were employed in diverse industries, these findings may well be representative of the general experience of MBA graduates some years after completing their degree. In a related but independent study, the employers of these MBA graduates were asked the same question, namely to rank a number of management disciplines in order of importance in the current as well as the expected future business situation in South Africa (Otto, 1997). Once again, Financial Management was rated as the most important subject. 
Other similar surveys have produced essentially the same results (Bosch, Radder, Tait \& Venter, 1994; Olivier, 1998).

One possible explanation for such high ratings could perhaps be that a large number of managers may have rated Financial Management as second most important, after his/her own area of specialisation had been ranked. If this happened often enough across a number of management fields, it would not be surprising that Financial Management took the overall first place.

Firer (1990:21) has suggested that Finance may well emerge as the key subject in the MBA curriculum. Ellis and Williams (1993:4) have argued, that to judge a company's strategic position and probable direction requires a synthesis of both real (e.g. quality of management, products, markets) and financial factors (e.g. profitability, cash flow, debt levels) in order to fully assess the company and its likely future stock market performance. On the basis of these considerations, one concludes that if Finance is not the most important business discipline, then it should be very close to the top.

\section{QUESTIONS TO BE ANSWERED}

If Financial Management can be generally regarded as an important discipline in a manager's repertoire, what is the relative importance of different topics in the field of Finance? Also, what are the possible differences between academics and practitioners with regard to these topics? To put it more formally, answers to the following questions are needed:

- Are there some topics in Finance that might be regarded as more important than others for a general manager?

- Are there differences in the way that academics and practitioners rate various topics in Finance?

- Which topics in Finance do practitioners regard more important than others, and how does this compare with the topics that academics regard as more important?

- Which topics in Finance do practitioners regard less important than others, and how does this compare with the topics that academics regard as less important?

- Are there areas in Finance that practitioners believe should deserve more attention than others in the education of future South African managers?

- Are there areas in Finance that practitioners would like researchers to focus on, to enhance the value of the discipline to South African managers? 
The aim of this paper is to find answers to these questions, that could be of value to a wide spectrum of role players. Anyone who has even a superficial interest in Finance, would be interested to know which topics in Finance have been found most useful until now.

If there are significant differences in the ratings of the various topics in Finance by academics and practitioners respectively, this could be of interest to both these groups. Academics need to keep in mind future training needs, and practitioners need to know where inputs should be made if future academic training is to get to grips with the problems that they experience.

An evaluation of the areas in Finance that both academics and practitioners regard as most important for a general manager, as well as those that are regarded of lesser importance, may be important to those who design the courses by means of which managers are trained in Finance. It may also be important to the designers of specialised courses for future financial managers. In addition, designers of courses need to know of possible areas that practitioners believe deserve more attention than others in the education of future managers. Finally, if practitioners believe that some areas in Finance deserve more attention by academic researchers, this is likely to affect the nature of future research.

\section{EMPIRICAL STUDY}

At a conference of SAFA (the South African Finance Association), participants were requested to rate different topics in Finance in order of their importance to a general manager in South Africa. The general structure of the topics set out by Gitman (1997) was followed. Respondents were asked to complete a twopage questionnaire, rating each topic according to importance on a 7-point scale. Although no questions were asked to determine whether all South African tertiary educational institutions were represented at the conference, the 30 responses obtained in this study may be regarded as representative of the South African academic community in the field of Finance.

In a second survey, a number of financial directors of companies listed on the Johannesburg Stock Exchange (JSE) were requested to complete the same questionnaire, with two additional questions. The first of these asked which single aspect of Finance, in the experience of these financial directors, needs more attention than others in the education of future managers, taking into account the changes in the new South Africa. The second question asked respondents to state which aspect(s) of Finance they believed academic researchers should focus on to enhance the value of Finance as a discipline to 
South African managers. Respondents were also offered a summary of the research findings, when completed, if they were interested.

The top 200 companies (in terms of market capitalisation on 31 December 1998) identified by the Bureau of Financial Analysis at the University of Pretoria and published by Finansies \& Tegniek (26 March 1999), were regarded, for the purpose of the study, as the companies which represented the greatest value in the South African private sector. An attempt was made to establish telephonic contact with the financial directors of all of these companies in order to seek their co-operation. A questionnaire was faxed to 134 of these financial directors. Of the questionnaires, 66 were returned, representing a $49 \%$ response rate, which could be regarded as sufficient, taking into account the nature of respondents' work and the claims on their time.

\section{RESULTS}

In Table 1, the results of the surveys of the two groups of respondents are given, in the form of means and standard deviations of how the various topics were rated.

Table 1 Means and standard deviations of topic rankings by academics and financial directors

\begin{tabular}{|c|c|c|c|c|c|c|c|}
\hline \multirow[t]{2}{*}{$\begin{array}{l}\text { Ques- } \\
\text { tion }\end{array}$} & \multirow[t]{2}{*}{ Topic } & \multicolumn{2}{|c|}{ Academics } & \multicolumn{2}{|c|}{$\begin{array}{l}\text { Financial } \\
\text { directors }\end{array}$} & \multirow[t]{2}{*}{$\begin{array}{l}\text { Signifi- } \\
\text { cance }\end{array}$} & \\
\hline & & Mean & S.D. & Mean & S.D. & & \\
\hline Q1 & The role of Finance in the firm & 5.50 & 1.96 & 6.39 & 0.80 & 0.002 & $* * *$ \\
\hline $\mathrm{Q2}$ & The income statement & 4,90 & 1.40 & 5.95 & 1.00 & .001 & *** \\
\hline Q3 & alance sheet & 4.90 & 1.42 & 5.61 & 1.04 & 0.007 & $* * *$ \\
\hline $\mathrm{Q} 4$ & The cash $\mathrm{f}$ & 5.77 & 1.04 & 5.76 & 1.40 & .975 & \\
\hline Q5 & Understanding financial I & 5.20 & 1.45 & 5.05 & 1.28 & .601 & \\
\hline Q6 & Time value of money & 5.43 & 1.72 & 5.31 & 1.39 & .728 & \\
\hline Q7 & Risk & & 1.59 & 5.82 & 1.08 & .506 & \\
\hline Q8 & $\mathrm{Va}$ & & 1.85 & 3.92 & 1.33 & 0.129 & \\
\hline Q9 & $\begin{array}{l}\text { Cash flow and capital } \\
\text { budgeting }\end{array}$ & 6.03 & 1.03 & 5.65 & 1.27 & 0.153 & \\
\hline Q10 & Capital budgeting techniques & & 1.26 & 0 & 1.42 & 01 & ** \\
\hline Q11 & The cost of capital & 5.50 & 1.22 & 5.18 & 1.25 & 0.248 & \\
\hline Q12 & and capital structure & 4.87 & 1.48 & 4.76 & 1.48 & 0.738 & \\
\hline Q13 & Long-term debt & 4.47 & 1.36 & 4.48 & 1.27 & 0.949 & \\
\hline Q14 & Equity and stock markets & 4.17 & 1.29 & 4.21 & 1.34 & 0.877 & \\
\hline
\end{tabular}


Table 1 continued

\begin{tabular}{|c|c|c|c|c|c|c|c|}
\hline \multirow[t]{2}{*}{$\begin{array}{l}\text { Ques- } \\
\text { tion }\end{array}$} & \multirow[t]{2}{*}{ Topic } & \multicolumn{2}{|c|}{ Academies } & \multicolumn{2}{|c|}{$\begin{array}{l}\text { Financial } \\
\text { directors }\end{array}$} & \multirow[t]{2}{*}{$\begin{array}{l}\text { Signifi- } \\
\text { cance }\end{array}$} & \\
\hline & & Mean & S.D. & Mean & S.D. & & \\
\hline Q15 & Efficient markets & 3.40 & 1.65 & 3.80 & 1.17 & 0.173 & \\
\hline Q16 & Dividend policy & 4.03 & 1.43 & 4.03 & 1.11 & 0.991 & \\
\hline Q17 & $\begin{array}{l}\text { Pref shares, convertibles, } \\
\text { warrants }\end{array}$ & 2.93 & 1.60 & 3.30 & 1.32 & 0.238 & \\
\hline$\overline{\mathrm{Q} 18}$ & $\begin{array}{l}\text { Short- and medium-term } \\
\text { financing }\end{array}$ & 5.10 & 0.99 & 4.55 & 1.38 & 0.051 & * \\
\hline Q19 & Cash and marketable securities & 4.47 & 1.57 & 3.89 & 1.18 & 0.049 & ** \\
\hline$\overline{\mathrm{Q} 20}$ & $\begin{array}{|lll|}\begin{array}{l}\text { Accounts receivable and } \\
\text { inventory }\end{array} & \\
\end{array}$ & 5.17 & 1.26 & 5.20 & 1.47 & 0.922 & \\
\hline Q21 & Mergers and acquisitions & 3.70 & 1.70 & 4.33 & 1.41 & 0,059 & $*$ \\
\hline $\mathrm{Q} 22$ & International Finance & 4.27 & 1.78 & 4.00 & 1.55 & 0.458 & \\
\hline $\mathrm{Q} 23$ & Futures, options, derivatives & 3.73 & 2.00 & 3.74 & 1.66 & 0.981 & \\
\hline Q24 & $\begin{array}{l}\text { Relationship with other } \\
\text { disciplines }\end{array}$ & 4.40 & 1.85 & 4.77 & 1.40 & 0.279 & \\
\hline Q25 & $\begin{array}{l}\text { Foreign exchange risk } \\
\text { management }\end{array}$ & 4.10 & 1.67 & 5.29 & 1.21 & 0.002 & $* * *$ \\
\hline Q26 & Value-based management & 5.14 & 1.38 & 4.92 & 1.37 & 0.487 & \\
\hline
\end{tabular}

A Multivariate Analysis of Variance (MANOVA) was performed in SAS (Statistical Analysis Systems) on the mainframe at the University of Pretoria to determine whether any elements of the two vectors of means are significantly different, taking into account the variance and the dependency of response (SAS Institute, 1985). Seeing that provision was made for possible correlation between questions, this procedure is more appropriate than the $26 \mathrm{~T}$-tests that might have been performed on the data. (If the T-tests had been performed, this would have capitalised on the level of significance, which would have increased the possibility of a Type II-error.)

From Table 1 it is evident that the mean ratings of different topics (each on a 7 point scale) are variable, ranging between 2.93 and 6.03 for academics (see also Table 2) and between 3.3 and 6.39 for financial directors (see also Table 3). From this it seems that both groups of respondents regard at least some topics in Finance more important than others. This would answer the first question posed above, but more evaluation is needed to determine whether these differences are significant. 
A PROC GLM procedure was also performed in SAS on both datasets individually, to determine whether, on average, respondents had rated Questions 1 to 26 in a similar manner or not. The most appropriate test here was the Waller-Duncan k-ratio t-test, performed on all main-effect means (SAS Institute, 1985:118, 487). The results are set out in tables 2 and 3 , where means with the same letter under "Grouping" are not significantly different at $p=0.05$. This indicates that some topics in Finance are regarded as significantly more important than others, in the opinion of both groups of respondents.

\section{DISCUSSION}

From Table 1 it is evident that the mean ratings differ significantly for eight of the 26 topics. Topics that financial directors regarded as significantly more important than academics did, are the role of Finance in the firm, the income statement, the balance sheet, mergers and acquisitions, and foreign exchange risk management. This could imply that these topics should be given more weight in academic courses than is the case at present.

Perhaps surprisingly, many topics were rated rather similarly by the two groups of respondents. These include the cash flow statement, long-term debt, equity and stock markets, dividend policy, accounts receivable and inventory, and futures, options and derivatives. The fact that these ratings are numerically almost the same, also indicates that the one group of respondents did not consistently rate some topics higher than the other group. (If such differences in ratings had occurred, the need for a scale transformation might have arisen, where only the relative ratings of the two groups could be compared. Fortunately, this was not the case.)

Academics rated the following topics as significantly more important than did financial directors: capital budgeting techniques, short- and medium-term financing, and cash and marketable securities. This could mean that these topics are, at present, receiving more attention in academic courses than practitioners believe to be necessary. In fact, there seem to be at least some significant differences in the perceived importance of the various topics in Finance, as seen by financial directors on the one hand and academics on the other. This answers the second question posed above.

Tables 2 and 3 give the relative rankings of financial topics by academics and financial directors respectively, indicated by the average score on a seven-point scale. If a topic was rated as more important, it had a high score; a relatively less important topic would again have a low score. The Waller grouping indicates that topics with the same letter are not rated significantly differently. 
This means, in Table 2, that cash flow and capital budgeting (Q9) are regarded as significantly more important than capital budgeting techniques (Q10), but not significantly more important than the time value of money (Q6).

Table 2 Ranking of topics by academics

\begin{tabular}{|c|c|c|c|c|c|c|c|}
\hline $\begin{array}{l}\text { Ran- } \\
\text { king }\end{array}$ & Question & Topic & Mean & \multicolumn{4}{|c|}{ Grouping } \\
\hline 1 & Q9 & Cash flow and capital budgeting & 6.03 & A & & & \\
\hline 2 & Q4 & The cash flow statement & 5.77 & A & $\mathbf{B}$ & & \\
\hline 3 & Q7 & Risk and return & 5.63 & A & $\mathrm{B}$ & & $\mathrm{C}$ \\
\hline 4 & $\mathrm{Q1}$ & The role of Finance in the firm & 5.50 & A & $\mathrm{B}$ & $\mathrm{D}$ & $\mathrm{C}$ \\
\hline 5 & Q11 & The cost of capital & 5.50 & A & B & $\mathrm{D}$ & $\mathrm{C}$ \\
\hline 6 & Q6 & Time value of money & 5.43 & A & B & $\mathrm{D}$ & $\mathrm{C}$ \\
\hline 7 & $\mathrm{Q} 10$ & Capital budgeting techniques & 5.30 & & B & $\mathrm{D}$ & $\mathrm{C}$ \\
\hline 8 & Q5 & Understanding financial ratios & 5.20 & & B & $\mathrm{D}$ & $\mathrm{C}$ \\
\hline 9 & $\mathrm{Q} 20$ & $\begin{array}{l}\text { Accounts receivable and } \\
\text { inventory }\end{array}$ & 5.17 & & B & D & $\mathrm{C}$ \\
\hline 10 & Q26 & Value-based management & 5.14 & & $\mathbf{B}$ & $\bar{D}$ & $\bar{C}$ \\
\hline 11 & Q18 & $\begin{array}{l}\text { Short- and medium-term } \\
\text { financing }\end{array}$ & 5.10 & $\mathbf{E}$ & & $\mathrm{D}$ & $\mathrm{C}$ \\
\hline 12 & $\mathrm{Q} 2$ & The income statement & 4.90 & $\mathrm{E}$ & $F$ & $\mathrm{D}$ & \\
\hline 13 & Q3 & The balance sheet & 4.90 & $\mathrm{E}$ & $F$ & $\mathrm{D}$ & \\
\hline 14 & $\mathrm{Q} 12$ & Leverage and capital str & 4.87 & $\mathrm{E}$ & $\mathrm{F}$ & $\mathrm{D}$ & \\
\hline 15 & Q13 & Long-term debt & 4.47 & $\mathrm{E}$ & $\mathrm{F}$ & & $\mathrm{G}$ \\
\hline 16 & Q19 & Cash and marketable securities & 4.47 & $\mathrm{E}$ & $\mathrm{F}$ & & $\mathrm{G}$ \\
\hline 17 & Q8 & Valuation of securities & 4.43 & & $\mathrm{~F}$ & & $\mathrm{G}$ \\
\hline 18 & Q24 & $\begin{array}{l}\text { Relationship with other } \\
\text { disciplines }\end{array}$ & 4.40 & & $\mathrm{~F}$ & & $G$ \\
\hline 19 & Q22 & International Finance & 4.27 & $\mathrm{H}$ & $\mathrm{F}$ & & $\mathrm{G}$ \\
\hline 20 & Q14 & Equity and stock markets & 4.17 & $\mathrm{H}$ & & & $\mathrm{G}$ \\
\hline 21 & Q25 & $\begin{array}{l}\text { Foreign exchange risk } \\
\text { management }\end{array}$ & 4.10 & $\mathrm{H}$ & & & $\mathrm{G}$ \\
\hline 22 & Q16 & Dividend policy & 4.03 & $\mathrm{H}$ & I & & $\mathrm{G}$ \\
\hline 23 & Q23 & Futures, options, derivatives & 3.73 & $\mathrm{H}$ & I & & \\
\hline 24 & $\mathrm{Q} 21$ & Mergers and acquisitions & 3.70 & $\mathrm{H}$ & I & & \\
\hline 25 & Q15 & Efficient markets & 3.40 & $\mathrm{~J}$ & I & & \\
\hline 26 & Q17 & $\begin{array}{l}\text { Pref shares, convertibles, } \\
\text { warrants }\end{array}$ & 2.93 & $\mathrm{~J}$ & & & \\
\hline
\end{tabular}


When the topics ranked in the first five places of tables 2 and 3 are compared, it is interesting to note that four of these five topics were seen to be important enough by both academics and financial directors to occupy one of the top five places. Thus both groups of respondents agreed that the role of Finance in the firm (Q1), risk and return (Q7), the cash flow statement (Q4) and cash flow and capital budgeting (Q9) are among the five most important topics in the ranking. This confirms the importance of a holistic view of the place of Finance, the important variables risk and return, as well as cash flow and its application.

\section{Table 3 Ranking of topics by financial directors}

\begin{tabular}{|c|c|l|l|c|c|c|}
\hline $\begin{array}{c}\text { Ran- } \\
\text { king }\end{array}$ & $\begin{array}{c}\text { Ques- } \\
\text { tion }\end{array}$ & Topic & & \multicolumn{3}{|l|}{ Grouping } \\
\hline 1 & Q1 & The role of Finance in the firm & 6.39 & A & & \\
\hline 2 & Q2 & The income statement & 5.95 & B & & \\
\hline 3 & Q7 & Risk and return & 5.82 & B & & \\
\hline 4 & Q4 & The cash flow statement & 5.76 & B & & \\
\hline 5 & Q9 & Cash flow and capital budgeting & 5.65 & B & C & \\
\hline 6 & Q3 & The balance sheet & 5.61 & B & C & D \\
\hline 7 & Q6 & Time value of money & 5.31 & E & C & D \\
\hline 8 & Q25 & Foreign exchange risk management & 5.29 & E & & D \\
\hline 9 & Q20 & Accounts receivable and inventory & 5.20 & E & F & \\
\hline 10 & Q11 & The cost of capital & 5.18 & E & F & \\
\hline 11 & Q5 & Understanding financial ratios & 5.05 & E & F & G \\
\hline 12 & Q26 & Value-based management & 4.92 & & F & G \\
\hline 13 & Q24 & Relationship with other disciplines & 4.77 & H & & G \\
\hline 14 & Q12 & Leverage and capital structure & 4.76 & H & & G \\
\hline 15 & Q18 & Short- and medium-term financing & 4.55 & H & I & \\
\hline 16 & Q13 & Long-term debt & 4.48 & H & I & \\
\hline 17 & Q21 & Mergers and acquisitions & 4.33 & J & I & \\
\hline 18 & Q10 & Capital budgeting techniques & 4.30 & J & I & \\
\hline 19 & Q14 & Equity and stack markets & 4.21 & J & I & K \\
\hline 20 & Q16 & Dividend policy & 4.03 & J & L & K \\
\hline 21 & Q22 & International Finance & 4.00 & J & L & K \\
\hline 22 & Q8 & Valuation of securities & 3.92 & & L & K \\
\hline 23 & Q19 & Cash and marketable securities & 3.89 & & L & K \\
\hline 24 & Q15 & Efficient markets & 3.80 & & L & \\
\hline 25 & Q23 & Futures, options, derivatives & 3.74 & & L & \\
\hline 26 & Q17 & Pref shares, convertibles, warrants & 3.30 & M & & \\
\hline
\end{tabular}


If the first ten places are compared, more topics are added to this list, namely, the time value of money (Q6), accounts receivable and inventory (Q20) and the cost of capital (Q11). Notably absent from the first ten places ranked by academics, are the income statement (Q2), the balance sheet (Q3) and foreign exchange risk management (Q25), which confirms the results set out in Table 1. The third question posed above as to which topics are regarded more important by both groups, has now been answered.

When one compares the topics ranked in the last five places in tables 2 and 3 , it is clear that the topics futures, options and derivatives (Q23), efficient markets (Q15) and preference shares, convertibles and warrants (Q17) were regarded by both groups of respondents as among the least important to them. Both groups seemed to agree that these topics could be regarded as rather specialised and therefore not quite as important to someone who needs a general knowledge of Finance.

If one compares the last ten positions as ranked by both groups, more topics are added to the "less important" list. These include valuation of securities (Q8), equity and stock markets (Q14), dividend policy (Q16), mergers and acquisitions (Q21) and international finance (Q22). This does not mean that these are totally unimportant topics, but rather they are considered less important, at least for a general manager. From the Waller grouping in tables 2 and 3 , one can also see that some of these topics were rated as significantly less important than many other topics. The fourth question posed above, as to which topics are regarded as less important by both groups, has now also been answered.

Table 4 Topics in need of more attention in training future managers, and topics in need of more research, as perceived by practitioners

\begin{tabular}{|c|l|l|c|c|c|}
\hline $\begin{array}{l}\text { Ques- } \\
\text { tion }\end{array}$ & Topic & $\begin{array}{l}\text { More } \\
\text { Attention }\end{array}$ & $\begin{array}{l}\text { Needs } \\
\text { research }\end{array}$ & \\
\hline & & Frequency & $\%$ & Frequency & $\%$ \\
\hline Q1 & The role of Finance in the firm & 4 & 17 & 2 & 5 \\
\hline Q2 & The income statement & 0 & 0 & 0 & 0 \\
\hline Q3 & The balance sheet & 0 & 0 & 0 & 0 \\
\hline Q4 & The cash flow statement & 4 & 17 & 5 & 12 \\
\hline Q5 & Understanding financial ratios & 4 & 17 & 8 & 20 \\
\hline Q6 & Time value of money & 0 & 0 & 3 & 7 \\
\hline Q7 & Risk and return & 3 & 13 & 4 & 10 \\
\hline Q8 & Valuation of securities & 1 & 4 & 0 & 0 \\
\hline
\end{tabular}


Table 4 continued

\begin{tabular}{|c|c|c|c|c|c|}
\hline $\begin{array}{l}\text { Ques- } \\
\text { tion }\end{array}$ & Topic & \begin{tabular}{|l} 
More \\
Attention
\end{tabular} & & \begin{tabular}{|l|l|} 
Needs \\
research
\end{tabular} & \\
\hline & & Frequency & $\%$ & Frequency & $\%$ \\
\hline Q9 & $\begin{array}{l}\text { Cash flow and capital } \\
\text { budgeting }\end{array}$ & 2 & 8 & 1 & 2 \\
\hline Q10 & Capital budgeting techniques & 0 & 0 & 2 & 5 \\
\hline Q11 & The cost of capital & 0 & 0 & 1 & 2 \\
\hline Q12 & Leverage and capital structure & 1 & 4 & 0 & 0 \\
\hline Q13 & Long-term debt & 0 & $\overline{0}$ & 0 & 0 \\
\hline Q14 & Equity and stock markets & 0 & 0 & 0 & 0 \\
\hline Q15 & Efficient markets & 0 & 0 & 0 & 0 \\
\hline Q16 & Dividend policy & 0 & 0 & 0 & 0 \\
\hline Q17 & $\begin{array}{l}\begin{array}{l}\text { Pref shares, convertibles, } \\
\text { warrants }\end{array} \\
\end{array}$ & 0 & 0 & 0 & 0 \\
\hline Q18 & $\begin{array}{l}\text { Short- and medium-term } \\
\text { financing }\end{array}$ & 0 & 0 & 0 & 0 \\
\hline Q19 & Cash and marketable securities & 0 & 0 & 0 & 0 \\
\hline Q20 & $\begin{array}{lll}\begin{array}{l}\text { Accounts } \\
\text { inventory }\end{array} & \text { receivable and } \\
\end{array}$ & 0 & 0 & 0 & 0 \\
\hline Q21 & Mergers and acquisitions & 0 & 0 & 1 & 2 \\
\hline Q22 & International Finance & 1 & 4 & 0 & 0 \\
\hline $\mathrm{Q} 23$ & Futures, options, derivatives & 0 & 0 & 2 & 5 \\
\hline Q24 & $\begin{array}{|lcc|}\begin{array}{l}\text { Relationship } \\
\text { disciplines }\end{array} & \text { with } & \text { other } \\
\end{array}$ & 0 & 0 & 1 & 2 \\
\hline Q25 & \begin{tabular}{|l|l|}
$\begin{array}{l}\text { Foreign exchange risk } \\
\text { management }\end{array}$ & \\
\end{tabular} & 0 & 0 & $\overline{0}$ & 0 \\
\hline Q26 & Value-based management & 4 & 17 & 11 & 27 \\
\hline & Total & 24 & 100 & 41 & 100 \\
\hline
\end{tabular}

In two of the questions above, financial directors were given the opportunity to share some of their perceptions of future developments. The responses to these questions were roughly classified in the structure of the original questionnaire, to identify the principles involved here. If a respondent indicated, for example, that "valuation of a company" needed more emphasis during training, it was reasoned that the same principles apply as those in the case of "valuation of securities". The results of the responses to these questions, set out in Table 4 should thus be regarded as an attempt to interpret the principles indicated by respondents.

The fifth question posed above relates to areas in Finance that practitioners believe deserve more attention in the education of future South African 
managers, taking into account the changes in the new South Africa. Only 24 respondents answered this question. Prominent topics here (each receiving 17\% of the response) are: the role of Finance in the firm, the cash flow statement, understanding financial ratios, and value-based management.

The sixth question in the study asked whether there are areas in Finance that practitioners would like researchers to focus on, to enhance the value of the discipline to South African managers. Only 41 respondents answered this question. Notable topics here are: value-based management ( $27 \%$ of response), understanding financial ratios (20\%), the cash flow statement $(12 \%)$, and risk and return $(10 \%)$. Thus it seems that there is a real need for research that would give South African managers a better understanding of financial statements, and ways of using the important topic of value-based management to their benefit.

\section{CONCLUSION}

From this study, it follows that some topics in Finance are indeed regarded more important than others by both academics and practitioners. These include the role of Finance in the firm, risk and return, the cash flow statement, and cash flow and capital budgeting. Topics generally regarded as least important (or so specialised that they are not part of general skills), include efficient markets, futures, options and derivatives, and preference shares, convertibles and warrants.

Topics that practitioners rated as significantly more important than the academics did, include the role of Finance in the firm, the income statement, the balance sheet, mergers and acquisitions, and foreign exchange management. Topics that academics again rated as significantly more important than the practitioners, include: capital budgeting techniques; short- and medium-term financing; and cash and marketable securities.

Although the focus here was on the relative importance of various topics in Finance to a typical general manager, the possibility cannot be excluded that the findings might also apply to any financial manager/director. This would then mean that the results of this study could be of interest to a fairly large circle of business leaders in South Africa. 


\section{AREAS FOR FURTHER RESEARCH}

Areas for further research include the ways in which Financial Management as a discipline can be made more valuable to management as a whole. This could be done, for example, by means of a survey in which practitioners would have the opportunity to disclose ways of presenting financial knowledge that they have found to be most helpful in the past. The extent to which different kinds of information technology, including simulation games, are used in educating financial as well as general managers could also be investigated. Is it true that there is a vast potential for the use of simulation games in a subject seen by managers as useful in their day-to-day work?

This study concerned the experience of financial practitioners in private companies. A similar study could be done on the experience of practitioners employed by government or semi-government institutions. Whereas the emphasis in this study fell on Financial Management, institutions that train future managers might also be interested in the relative importance of topics in other managerial disciplines. Finally, researchers should not ignore the topics that practitioners have identified as useful in raising the value of Financial Management to South African managers. The important topic of value-based management is one of these. Another is the ways of using financial ratios in the better management of an enterprise. Much has changed over the past few years, but for any enterprise, the bottom line is still that the bottom line is important.

\section{REFERENCES}

1 BOSCH, J.K., RADDER, L., TAIT, M. and VENTER, D.J.L. (1994) "Empiriese Bevindinge met betrekking tot Onderrigbehoeftes in Bedryfsekonomie", Management Dynamics, 3(2): 17-38.

2 ELLIS, J. \& WILLIAMS, D. (1993) Corporate Strategy and Financial Management, Pitman, London.

3 FINANSIES \& TEGNIEK (1999) 26 March 1999, Appendix: Top 200 Companies 1999.

4 FIRER, C. (1990) "Should MBA Students Study the Theory of Finance?", Investment Analysts Journal, Summer: 16-23.

5 GITMAN, L.J. (1997) Principles of Managerial Finance, AddisonWesley, New York. 8ed.

6 JONKER, W.D. (1997) A Follow Up Study on the Educational Experience of $M B A$ Graduates, Unpublished MBA dissertation. University of Pretoria, Pretoria. 
7 OLIVIER, G.J. (1998) Die Onderrig en Opleiding van Laevlakbestuurders, Unpublished $\mathrm{PhD}$ dissertation. Vista University, Pretoria.

8 OTTO, P.P. (1997) A Comparison of the Perceptions Regarding MBA studies of Different Stakeholders, Unpublished MBA dissertation. University of Pretoria, Pretoria.

9 SAS INSTITUTE (1985) SAS User's Guide, Sed., Cary, North Carolina. 